cứu của chúng tôi có kết quả tương đồng với kết quả ghi nhận trong các thử nghiệm lâm sàng của vắc xin Astrazeneca, kết quả cho thấy các tác dụng không mong muốn có thể xảy ra như sốt, ớn lạnh, đau đầu, sưng đau tại vị trú tiêm sau khi tiêm và tác dụng không mong muốn thường gặp là sưng đau tại vị trí tiêm. Tuy nhiên kết quả của chúng tôi khổng tương đồng về tỷ lệ xuất hiện tác dụng không mong muốn ở nhóm sau khi tiêm 2 mũi vắc xin cao hơn nhóm tiêm lần đầu, ngược lại với kết quả ghi nhận trong tờ hướng dẩn sử dụng vắc xin Astrazeneca, tần xuất xuất hiện phản ứng không mong muốn giảm ở nhóm sau khi tiêm vắc xin ở mũi thứ 2 [7].

\section{KẾT LUÂ̂N}

Nghiên cứu của chúng tôi đã tiến hành quan sát nồng độ kháng thể kháng vi rút SARS-Covid2 trên 80 đối tượng, chúng thấy các tác dụng không mong muốn được ghi nhận ở các thời điểm sau khi tiêm vắc xin 1 mũi và 2 mũi là sốt, ớn lạnh, đau đầu, đau mỏi người và đau sưng tại vị trí tiêm. Tỷ lệ gặp tác dụng không mong muốn ở 2 nhóm nhìn chung là tương đương. Kết quả định lượng IgG của mẫu nghiên cứu cho thấy $100 \%$ các nhóm đã tiêm vắc xin đều có đáp ứng miễn dịch với SAR-COVID-2 ngay từ mũi 1 và cao hơn so với nhóm chưa tiêm ít nhất 12 lần (nhóm tiêm 1 mũi) cho đến 71 lần (nhóm sau tiêm 2 mũi 2 tuần). Tiêm đủ 2 mũi vắc xin giúp cơ thể của các đối tượng nghiên cứu đạt được nồng độ kháng thể cao hơn rõ rệt so với khi tiêm 1 mũi. Nồng độ kháng thể kháng vi rút SARSCovid-2 vào 3 tuần sau tiêm mũi 2 nhỏ hơn so với nhóm sau tiêm vắc xin 2 tuần. Từ kết quả phân tích trên, chúng ta thấy rằng tiêm vắc xin phòng Covid-19 giúp sản sinh kháng thể chống lại vi rút SARS-CoV-2. Tuy nhiên, lượng kháng thể này khác nhau giữa các đối tượng và thay đổi theo thời gian sau khi tiêm phòng.

\section{TÀl LIỆU THAM KHẢO}

1. Forchette, L., W. Sebastian, and T. Liu, $A$ Comprehensive Review of COVID-19 Virology, Vaccines, Variants, and Therapeutics. Curr Med Sci, 2021: p. 1-15.

2. Jimenez, M., N.E. Campillo, and M. Canelles, COVID-19 Vaccine Race: Analysis of AgeDependent Immune Responses against SARS-CoV2 Indicates that more than Just One Strategy May Be Needed. Curr Med Chem, 2021. 28(20): p. 3964-3979.

3. Widge, A.T., et al., Durability of Responses after SARS-CoV-2 mRNA-1273 Vaccination. N Engl J Med, 2021. 384(1): p. 80-82

4. World Health, O., mRNA vaccines against COVID-19: Pfizer-BioNTech COVID-19 vaccine BNT162b2: prepared by the Strategic Advisory Group of Experts (SAGE) on immunization working group on COVID-19 vaccines, 22 December 2020. 2020, World Health Organization: Geneva.

5. Azzi, L., et al., Anti-SARS-CoV-2 RBD IgG responses in convalescent versus naïve BNT162b2 vaccine recipients. Vaccine, 2021. 39(18): p. 2489-2490.

6. Coughlin, M.M. and B.S. Prabhakar, Neutralizing human monoclonal antibodies to severe acute respiratory syndrome coronavirus: target, mechanism of action, and therapeutic potential. Rev Med Virol, 2012. 22(1): p. 2-17.

7. World Health, 0 . Interim recommendations for use of the ChAdOx1-S [recombinant] vaccine against COVID-19 (AstraZeneca COVID-19 vaccine AZD1222 Vaxzevria ${ }^{\mathrm{TM}}$, SII COVISHIELD ${ }^{\mathrm{TM}}$ ): interim guidance, first issued: 10 February 2021, updated: 21 April 2021, last updated: 30 July 2021. 2021, World Health Organization: Geneva.

\title{
KẾT QUẢ HÓA TRI PHÁC ĐỒ Có TS-1 TRONG ĐIỀU TRI UNG THƯ DẠ DÀY GIAI ĐOẠN MUỘN
}

\section{TÓM TẮT}

Mục tiêu: Đánh giá kết quả điều trị ung thư da dày giai đoạn muộn bắng hóa tri phác đồ có TS-1. Đối tượng và phương pháp nghiên cứu: 43 bệnh nhân

\author{
${ }^{1}$ Bệnh viện đa khoa tỉnh Nam Định \\ ${ }^{2}$ Trung tâm Y học hạt nhân và Ung bướu, Bệnh viện \\ Bach Mai \\ Chịu trách nhiệm chính: Đỗ Thái Hiền \\ Email: hiendothaih8@gmail.com \\ Ngày nhận bài: 21.6.2021 \\ Ngày phản biên khoa hoc: 16.8.2021 \\ Ngày duyệt bài: 24.8.2021
}

\section{Đỗ Thái Hiền' ${ }^{1}$ Phạm Cẩm Phương ${ }^{2}$}

được chẩn đoán ung thư da dày giai đoạn muộn, 31 bệnh nhân được điều trị bằng TS-1 kết hợp Cispaltin và 12 bệnh nhân được điều trị bằng TS-1 đơn thuân tại bệnh viện $K$ và Bệnh viện Bạch Mai từ tháng 1 năm 2020 đến tháng 4 năm 2021. Kết quả: Tuổi trung bình của nhóm nghiên cứu là 60,1 tuổi. Tỉ lệ nam/nữ là 2,9/1. 88,4\% bệnh nhân có chí số toàn trang $\mathrm{PS}=0$ 1. Ớ nhóm bệnh nhân được điều trị phác đồ TS-1 kết hợp Cisplatin cho kết quả $51,6 \%$ đáp ứng toàn bộ, không có đáp ứng hoàn toàn, $35,5 \%$ bệnh ổn định, $4 \%$ bênh tiến triển. Ớ nhóm điêu tri phác đồ TS-1 đơn trị cho kết quả $16,7 \%$ đáp ứng toàn bộ, không có đáp ứng hoàn toàn, $66,6 \%$ bênh ổn đinh và $2 \%$ bênh tiến triển. Kết luận: Phác đồ chứa TS-1 có hiệu quả kiểm 
soát bệnh ở những bệnh nhân ung thư dạ dày giai đoạn muộn. hóa trị.

Tư khóa: ung thư dạ dày giai đoạn muộn, TS-1,

\section{SUMMARY \\ OUTCOME OF TS-1 BASED REGIMENS FOR ADVANCED GASTRIC CANCER}

Objective: Evaluating the treatment outcomes of chemotherapy with TS-1 for advanced gastric cancer. Patients and method: 43 advanced gastric cancer patients, 31 patients were assigned to TS-1 plus Cisplatin and 12 patients were assigned to TS-1 alone regimes at $\mathrm{K}$ Hospital and Bach Mai Hospital from January 2020 to April 2021. Results: The mean age of study group was 60.1 years. $88.4 \%$ patients had good performance status $P S=0-1$. In the TS- 1 plus Cisplatin group, $51.6 \%$ patients had total responses, no completed response, $35.5 \%$ patients had stable disease and $4 \%$ patients had progressive disease. In the TS-1 alone group, $16.7 \%$ patients had total responses, no completed response, $66.6 \%$ patients had stable disease and $2 \%$ patients had progressive disease. Conclusion: TS-1 has some effect on controlling advanced gastric cancer.

Key words: advanced gastric cancer, TS-1, chemothepary.

\section{I. ĐĂT VẤN ĐỀ}

Ung thư da dày (UTDD) là bệnh ung thư hay gặp ở nước ta và một số nước trên thế giới. Cho đến nay, mặc dù đã có những tiến bộ nhất định trong chẩn đoán và điều trị, nhưng tiên lượng bệnh vẫn chưa thay đổi nhiều. Tỉ lệ mắc UTDD có xu hướng giảm trên toàn thế giới trong vài thập kỷ qua nhưng vẫn là nguyên nhân thứ 4 gây tử vong do các bệnh ung thư trên toàn cầu.

Phẫu thuật là phướng pháp điều trị cơ bản và quan trọng bệnh ung thư dạ dày. Các biện pháp hóa chất, xạ trị và điều trị nhắm trúng đích có vai trò bổ trợ hoặc điều trị triệu chứng. Lựa chọn điều trị phụ thuộc vào mức độ xâm lấn u, tình trạng di căn hạch, giai đoạn, thể mô bệnh học,... Bểnh có tiên lượng tốt khi phát hiện sớm, đặc biệt là trước giai đoạn T1N0. Tuy nhiên, bệnh thường biểu hiện triệu chứng khi đã ở giai đoạn muộn, tổn thương đã xâm lấn, lan rộng, không còn khả năng phẫu thuật triệt căn.

Trong trường hợp bệnh ở giai đoạn muộn, hóa trị là phương pháp hiệu quả để giảm nhẹ triệu chứng, nâng cao chất lượng cuộc sống và kéo dài thời gian sống thêm. Hiện nay, nhiều phác đồ hóa chất cùng với liệu pháp nhắm trúng đích đã chứng minh được lợi ích trong điều trị. Các phác đồ dựa trên 5-FU là căn bản, các thế hêe mới của phẩn tử này đã được nghiên cứu và đưa vào thực hành lâm sàng để cải thiện lợi ích và giảm tác dụng phụ.
Tại Việt Nam, bệnh nhân thường phát hiện khi bệnh đã ở giai đoạn muộn, thể trạng chung kém, TS-1 là một lựa chọn hợp lý cho nhóm bệnh nhân này. Dược chất này đã được áp dụng vào điều trị UTDD ở nước ta những năm gần đây. Tuy nhiên cho đến nay có rất ít nghiên cứu đánh giá đầy đủ kết quả điều trị cũng như tác dụng không mong muốn của TS-1 khi điều trị tại Việt Nam. Vì vậy, chúng tôi tiến hành nghiên cứu đề tài này với mục tiêu đánh giá kết quả của phác đồ có TS-1 trong điều trị UTDD giai đoạn muộn.

\section{II. ĐỐI TƯƠNGG VÀ PHƯƠNG PHÁP NGHIÊN CỨU}

2.1. Đối tượng nghiên cứu: Bao gồm các bệnh nhân được chẩn đoán là ung thư dạ dày giai đoạn muộn được điều trị bằng phác đồ có TS-1 tại bệnh viện $K$ và Bệnh viện Bạch Mai từ tháng 1 năm 2020 đến tháng 4 năm 2021 thỏa mãn các tiêu chuẩn sau:

\section{Tiêu chuẩn lựa chọn}

- Bệnh nhân được chẩn đoán xác định ung thư dạ dày giai đoạn tiến triển tại chỗ, tại vùng hoặc di căn xa và được hóa trị phác đồ TS-1 đơn trị hoặc TS-1 kết hợp Cispatin.

- Điểm toàn trạng theo ECOG 0-2.

- Các chỉ số chức năng tủy xương, chức năng gan thận trong giới hạn cho phép điều trị hóa chất.

- Được điều trị ít nhất 3 chu kỳ hóa chất.

- Có hồ sơ lưu trữ đầy đủ.

\section{Tiêu chuấn loại trừ}

- Đã và đang điêu trị một bệnh ung thư khác.

- Mẫn cảm hay dị ứng với TS-1, Cisplatin.

- Mắc các bệnh cấp hoặc mạn tính trâm trọng.

- Phụ nữ mang thai, cho con bú.

2.2. Phương pháp nghiên cứu

Thiết kế nghiên cứu: Nghiên cứu mô tả cắt ngang.

Thu thập số liệu: theo một mẫu bệnh án nghiên cứu thống nhất dựa trên hồ sơ bệnh án.

Phác đồ nghiên cứu:

- Phác đồ TS-1 kết phợp Cisplatin:

TS-1: Liều lượng TS-1 tính theo diện tích bề mặt cơ thể bệnh nhân như sau: dưới 1,25 $\mathrm{m}^{2}: 40$ $\mathrm{mg} ; 1,25-1,5 \mathrm{~m}^{2}: 50 \mathrm{mg}$; > 1,5m²: 60mg. Thuốc được dùng bằng đường uống, 2 lần mỗi ngày trong 2 tuần liên tiếp.

Cisplatin: liều $60 \mathrm{mg} / \mathrm{m}^{2}$, được pha với dung dịch Natriclorid $0,9 \%$, truyền tĩnh mạch vào ngày 1 .

Chu kỳ 21 ngày.

- Phác đồ TS-1 đơn trị:

TS-1: Liều lượng TŚ-1 tương tự liều TS-1 trong phác đồ kết hợp Cispaltin. Thuốc được dùng bằng đường uống, 2 lần mỗi ngày trong 4 
tuần liên tiếp. Chu kỳ 6 tuần.

Thu thập và xử lý số liệu: bằng phần mềm SPSS 16.0 .

\section{KẾT QUẢ NGHIÊN CỨU VÀ BÀN LUÂ̂N}

\section{1. Đặc điểm bênh nhân}

Bảng 1. Đặc điểm bệnh nhân

\begin{tabular}{|c|c|c|c|}
\hline \multicolumn{2}{|c|}{ Đặc điểm } & n & Tỉ lệ \% \\
\hline \multirow{3}{*}{ Tuổi } & $\begin{array}{c}\text { Tuối trung } \\
\text { bình }\end{array}$ & \multicolumn{2}{|c|}{$60,1 \pm 10,7$} \\
\cline { 2 - 4 } & Cao nhất & \multicolumn{2}{|c|}{86} \\
\cline { 2 - 4 } & Thấp nhất & \multicolumn{2}{|c|}{33} \\
\hline \multirow{2}{*}{ Giới tính } & Nam & 32 & 74,4 \\
\cline { 2 - 4 } & Nũ̃ & 11 & 25,6 \\
\hline Giai đoạn & IV & 28 & 65,1 \\
\cline { 2 - 4 } & Tái phát & 15 & 34,9 \\
\hline \multirow{2}{*}{$\begin{array}{c}\text { Thế trạng } \\
\text { chung trước } \\
\text { điều trị }\end{array}$} & PS 0 - 1 & 38 & 88,4 \\
\cline { 2 - 4 } & PS 2 & 5 & 11,6 \\
\hline
\end{tabular}

Nhận xét: Tuối trung bình của đối tượng nghiên cứu là 60,14 . Tỉ lệ nam/ nữ là 2,9/1. Đa số $(56,1 \%)$ bệnh nhân di căn xa ngay tại thời điểm chẩn đoán, 34,9\% bệnh nhân ở giai đoạn tái phát không còn khả năng phẫu thuật triệt cằn lại. Hầu hết $(88,4 \%)$ bệnh nhân có thể trạng chung trước điêu trị tốt (PS 0-1).

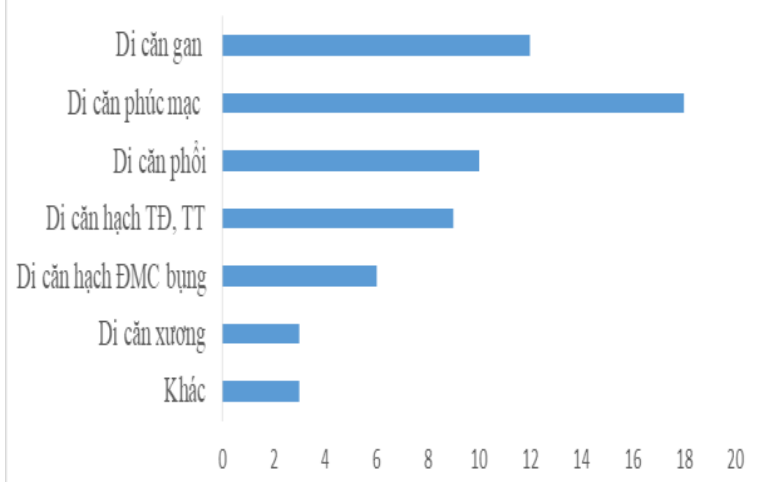

Biêu đồ 1. Đặc điểm vị trí di căn

Nhận xét: Di căn phúc mạc hay gặp nhất với tỉ lệ $41,9 \%$.

\subsection{Vê đáp ứng điêu trị}

Bảng 2. Liệu trinh điều trị

\begin{tabular}{|c|c|c|c|c|c|c|c|}
\hline \multirow{2}{*}{ Liệu trình điều trị } & \multicolumn{2}{c|}{ TS-1 + Cisplatin } & \multicolumn{2}{c|}{ TS -1 đơn trị } & \multicolumn{2}{c|}{ Tống } \\
\cline { 2 - 8 } & $\mathbf{n}$ & $\mathbf{\%}$ & $\mathbf{n}$ & $\mathbf{\%}$ & $\mathbf{n}$ & $\mathbf{\%}$ \\
\hline \multirow{2}{*}{$\begin{array}{c}\text { Liều điều } \\
\text { trị }\end{array}$} & Dưới $85 \%$ & 2 & 6,5 & 1 & 8,3 & 3 & 7,0 \\
\cline { 2 - 8 } & $85-100 \%$ & 29 & 93,5 & 11 & 91,7 & 40 & 93,0 \\
\hline \multirow{2}{*}{$\begin{array}{c}\text { Số chu } \\
\text { kỳ điêu } \\
\text { trị }\end{array}$} & 3 & 3 & 9,7 & 4 & 1 & 4 & 9,3 \\
\cline { 2 - 8 } & $4-6$ & 13 & 41,9 & 15 & 2 & 15 & 34,9 \\
\cline { 2 - 8 } & $>6$ & 15 & 48,4 & 24 & 9 & 24 & 55,8 \\
\hline \multicolumn{2}{c}{} & $\mathbf{1 2}$ & $\mathbf{1 0 0}$ & $\mathbf{3 1}$ & $\mathbf{1 0 0}$ & $\mathbf{4 3}$ & $\mathbf{1 0 0}$ \\
\hline
\end{tabular}

Nhận xét: Hầu hết $(93,5 \%)$ bệnh nhân được điều trị liều từ 85 - 100\%. Bệnh nhân điều trị đủ 6 chu kỳ ở các phác đồ là $69,8 \%$.

Bảng 3. Đáp ứng điều trị

\begin{tabular}{|c|c|c|c|c|c|}
\hline & \multicolumn{2}{|c|}{ TS-1 + Cisplatin } & \multicolumn{2}{|c|}{ TS-1 đơn trị } \\
\hline & & $\mathbf{n}$ & $\%$ & $\mathbf{n}$ & $\%$ \\
\hline \multirow{2}{*}{$\begin{array}{l}\text { Có } \\
\text { đáp ứng }\end{array}$} & Đáp ứng hoàn toàn & 0 & 0 & 0 & 0 \\
\hline & Đáp ứng một phần & 16 & 51,6 & 2 & 16,7 \\
\hline \multirow{2}{*}{$\begin{array}{l}\text { Không } \\
\text { đáp ứng }\end{array}$} & Bệnh ốn định & 11 & 35,5 & 8 & 66,6 \\
\hline & Bệnh tiến triến & 4 & 12,9 & 2 & 16,7 \\
\hline \multicolumn{6}{|c|}{$p<0.05$} \\
\hline \multicolumn{2}{|c|}{ Tỉ lệ có Iợi ích lâm sàng } & \multicolumn{2}{|c|}{87,1} & \multicolumn{2}{|c|}{83,3} \\
\hline
\end{tabular}

Nhận xét: Tỉ lệ có đáp ứng của phác đồ TS-1 + Cisplatin là $51,6 \%$, của phác đồ TS- 1 đơn trị là $16,7 \%$. Sự khác biệt có ý nghĩa thống kê $(p<0,05)$. Tỉ lệ có lợi ích lâm sàng của hai phác đồ tương đương nhau $87,1 \%$ và $83,3 \%$ ( $p>0,05)$. Không có bệnh nhân nào đạt đáp ứng hoàn toàn.

\section{BÀN LUÂ̂N}

4.1. Về đặc điểm bệnh nhân. Nghiên cứu của chúng tôi được tiến hành trên 43 bệnh nhân ung thư dạ dày giai đoạn muộn. Trong đó, 31 bệnh nhân được điều trị phác đồ TS-1 kết hợp Cisplatin, 12 bệnh nhân được điều trị phác đồ TS-1 đơn trị. Có $28 / 43$ bệnh nhân $(65,1 \%)$ bệnh nhân di căn xa ngay tại thời điểm chẩn đoán, 15/43 bệnh nhân (34,9\%) ở giai đoạn tái phát không còn khả năng phẩu thuật triệt căn lại. Tuổi trung bình của các bệnh nhân là 60,1 tuổi. Kết quả này tương đồng với các tác giả trong nước và nước ngoài như nghiên cứu của Nguyễn Minh Phương (2020) tuổi trung bình của nhóm 
bệnh nhân giai đoạn muộn là 58,8 , nghiên cứu của Ajani và CS (2011) là 59 hay như của nhóm nghiên cứu Koizumi (2008) là 62 tuổi. Tỉ lệ nam/nữ là 2,9/1, tương tự kết quả nghiên cứu của Koizumi và cộng sự $(2,7 / 1)$, cao hơn nghiên cứu của Phan Quang Đạt $(1,8 / 1)$. Thể trạng chung của bệnh nhân trong nghiên cứu tương đối tốt, 38 BN có $P S=0-1$, chiếm $88,4 \%$, chỉ có $5 \mathrm{BN}$ có $\mathrm{PS}=2$, chiếm $11,6 \%$.

Trong số các bệnh nhân có di căn xa trong nghiên cứu của chúng tôi, vị trí di căn hay gặp nhất là di căn phúc mạc chiếm $41,9 \%$, tiếp đến là di căn gan chiếm $27,9 \%$ và di căn phổi chiếm 23,3\%. Nghiên cứu của Nguyễn Minh Phương (2020) cho thây bệnh nhân ung thư da dày di căn thì phúc mạc là vị trí di căn hay gặp nhất, chiếm $47,6 \%$, di căn gan chiếm $31 \%$ và di căn phổi chiếm 23,8\%. Tỉ lệ di căn hạch động mạch chủ bụng trong nghiên cứu của Tô Như Hạnh (2012) chiếm 19,4\%, tương tự trong nghiên cứu của chúng tôi là $20,9 \%$. Những vị trí như xương, tuyến thượng thận, buồng trứng ở nữ... có tỉ lệ thấp hơn. Nghiên cứu của Koizumi và CS (2008) cũng cho thây di căn hạch có tỉ lệ cao nhất $(62,75 \%)$, tiếp đến là di căn phúc mạc $(60,4 \%)$ và di căn gan $(36,2 \%)$. Như vậy, kết quả thống kê cho thấy mô hình bệnh lý di căn UTDD trong nghiên cứu của chúng tôi có nhiều điểm tương đồng so với các nghiên cứu của các tác giả trong và ngoài nước.

4.2. Về đáp ứng điều trị. Trong nghiên cứu của chúng tôi, có 40 bệnh nhần được điều trị liều từ $85-100 \%$, chiếm $93 \%$. Chỉ có 3 bệnh nhân điều trị liều dưới $85 \%$ do tuổi già, có nhiều bệnh lý nền phối hợp, thể trạng yếu. Tỉ lệ được điều trị liều từ $85-100 \%$ ở hai nhóm điều trị TS-1 đơn thuần và TS-1 kết hợp Cisplatin là tương đương nhau. Số bệnh nhân được điều trị 4 - 6 chu kỳ trong nghiên cứu của chúng tôi chiếm $34,9 \%$, Số bệnh nhân điêuu trị từ 7 chu kỳ là $55,8 \%$ cao hơn trong nghiên cứu của Tô Như Hạnh khi nghiên cứu hiệu quả phác đồ EOX trên BN UTDD giai đoạn muộn, số bệnh nhân điều trị $4-6$ chu kỳ là $20,6 \%$. Tỉ lệ này trong nghiên cứu của Nguyê̂n Minh Phương (2020), đánh giá hiệu quả của phác đồ TS-1 kết hợp Cisplatin tở BN UTDD giai đoạn muộn là $40,5 \%$. Có 3 bệnh nhân chỉ điều trị 3 chu kỳ do bệnh tiến triển, 1 bệnh nhân chuyển phác đồ do tác dụng phụ của thuốc.

Nghiên cứu của chúng tôi đánh giá tại thời điểm kết thúc 3 chu kỳ hóa chất cho thấy: trong 31 bệnh nhân được điều trị phác đồ TS-1 kết hợp Cisplatin có 16 bệnh nhân đáp ứng một phần, không có bệnh nhân nào đạt đáp ứng hoàn toàn, tỉ lệ đáp ứng toàn bộ là $51,6 \%$; trong 12 bệnh nhân điều trị phác đồ TS-1 có 2 bệnh nhân đáp ứng một phần, không có bệnh nhân nào đáp ứng hoàn toàn, đáp ứng toàn bộ đạt $16,7 \%$. Tỉ lệ đáp ứng của hai phác đồ khác nhau có ý nghĩa thống kê, với $p<0,05$. Nghiên cứu về hiệu quả của phác đồ TS-1 kêt hợp Cisplatin trên bệnh nhân UTDD giai đoạn muộn, Koizumi và CS (2008) cho thây tî lệ đáp ứng toàn bộ là $54 \%$ 47/87 bệnh nhân, còn nghiên cứu của Nguyễn Minh Phương (2020) cho thấy tỉ lệ đáp ứng toàn bộ là $54,8 \%$, của Ajani và CS (2013), tỉ lệ đáp ứng toàn bộ chiếm 29,1\%. Như vậy kết quả tỉ lệ đáp ứng toàn bộ của phác đồ TS-1 kết hợp Cisplatin nghiên cứu của chúng tôi tương đồng với kết quả nghiên cứu của các tác giả khi nghiên cứu trên nhóm bệnh nhân Châu Á. Nghiên cứu về hiệu quả cúa phác đồ TS-1 đơn trị ở nhóm bệnh nhẩn UTDD giai đoạn muộn, cũng trong nghiên cứu của Koizumi và cộng sự 2008 cho kết quả tỉ lệ đáp ứng là $31 \%$, nghiên cứu của Lee và CS (2011) là 39,2\%, nghiên cứu của Narahara và CS (2011) là 26,9\%. Kết của của chúng tôi thấp hơn nghiên cứu của các tác giả trên.

Tî lệ bệnh ổn định và tỉ lệ kiểm soát bệnh trong nghiên cứu của chúng tổi cao hơn của các tác giả này. Kết quả trong nghiên cứu của chúng tôi đối cho thấy điều trị với phác đồ TS-1 kết hợp Cisplatin cho tỉ lệ bệnh ổn định là $35,5 \%$, tỉ lệ kiểm soát bệnh đạt $87,1 \%$, phác đồ TS- 1 đơn trị cho tỉ lệ bệnh ổn định $66,6 \%$, tỉ lệ kiểm soát bệnh $83,4 \%$. Tỉ lệ kiểm soát bệnh của hai phác đồ trong nghiên cứu của chúng tôi có kết quả tương đương nhau $(p>0,05)$.

\section{KẾT LUÂN}

Tuổi trung bình 60,1 tuổi. Tỉ lệ nam/nữ là $2,9 / 1$. Có $65,1 \%$ BN di căn xa ngay tại thời điểm chẩn đoán, 34,9\% ở giai đoạn tái phát không còn khả năng phẫu thuật triệt căn lại. Vị trí di căn hay gặp nhất là di căn phúc mạc và di căn hạch, đều chiếm $41,9 \%$, tiếp đến là di căn gan chiếm $27,9 \%$ và di căn phổi chiếm $23,3 \%$. Đa số bệnh nhân có thể trạng chung tốt trước điều trị, PS 0-1 (88,4\%).

31 bệnh nhân điều trị phác đồ TS-1 kết hợp Cisplatin cho kết quả $51,6 \%$ đáp ứng toàn bộ, không có đáp ứng hoàn toàn, $35,5 \%$ bệnh ổn định, $4 \%$ bệnh tiến triển. 12 bệnh nhân điều trị phác đồ TS-1 đơn trị cho kết quả 16,7\% đáp ứng toàn bộ, không có đáp ứng hoàn toàn, $66,6 \%$ bệnh ổn định và $2 \%$ bệnh tiến triển. Tỉ lệ kiểm soát bệnh của hai phác đồ lần lượt là $87,1 \%$ và $83,4 \%$. 
Phác đồ chứa TS-1 là một lưa chọ hợp lý cho bệnh nhân ung thư dạ dày giai đoạn muộn.

\section{TÀI LIÊU THAM KHẢO}

1. Bô Y tế (2020). Hướng dẫn chẩn đoán và điều trị bệnh ung thư dạ dày.

2. GLOBOCAN Cancer fact sheets: stomach (2020). https://gco.iarc.fr/today/data/factsheets/cancers/7 -Stomach-fact-sheet.pdf

3. Koizumi W, Narahara $\mathbf{H}$, Hara $\mathbf{T}$, Takagane A, Akiya T, Takagi M, et al (2008). TS-1 plus cisplatin versusTS-1 alone for first-line treatment of advanced gastric cancer (SPIRITS trial): A phase III trial. Lancet Oncol, 9, 215-21.

4. Nguyến Minh Phương (2020). Đánh giá kết quả phác đồ TS-1 - Cispaltin trong điều trị bước một ung thư da dày giai đoạn muộn tại bệnh viện $K$. Trường Đại học Y Hà Nội.

5. Ter Veer, E. et al. The efficacy and safety of S-1based regimens in the first-line treatment of advanced gastric cancer: a systematic review and meta-analysis. Gastric Cancer 19, 696-712 (2016).

\section{KẾT QUẢ ĐIỀU TRI BIẾN CHỨNG DO XẠ TRỊ UNG THƯ CỔ TỬ CUNG}

\section{TÓM TẮT}

Mục Đích: Đánh giá kết quả điều trị biến chứng do xạ trị ung thư cổ tứ cung. Phương pháp: Nghiên cứu hiồi cứu trên 37 bệnh nhân được chẩn đoán biến chứng tiêu hóa, sinh dục, tiết niệu do xa trị ung thư cổ tử cung được phẫu thuật tại bệnh viện Việt Đức từ 2/2007 đến 12/2020. Kết quả: $100 \%$ BN có loét trực tràng chảy máu, trong đó 18 bệnh nhân $(48,6 \%)$ có biến chứng hẹp và rò vào tạng sinh dục, tiết niệu. Một số biến chứng về sinh dục tiết niệu khác: viêm bàng quang 8 BN $(21,6 \%)$, hẹp niệu quản 8 BN $(21,6 \%)$, hẹp âm đạo (không rò vào trực tràng) $26 \mathrm{BN}(70,3 \%)$. Chỉ đinh mổ chủ yếu do viêm loét trực tràng chảy máu 19/37 bệnh nhân (51,4\%). Phẫu thuật cắt loại trừ thương tổn (PT Mille và Hartmann) là chủ yếu $27 \mathrm{BN}$, chiếm tỉ lệ 73\%. Cắt trực tràng, tứ cung, BQ, nối ĐTÔHM + HMNT 6/37 bệnh nhân (16,2\%). Khống có tai biến, biến chứng nặng sau mổ, không có tử vong. Kết quả lâu dài, 7 bệnh nhân đã chết do ung thư tái phát tại chỗ, hoặc u di căn, chiếm tỷ lệ 19\%. Các bệnh nhân sau mổ khỏe mạnh, tham gia sinh hoạt cộng đồng tương đối bình thường, không còn chảy máu tiêu hóa. Kết luận: xạ trị ung thư cổ tử cung còn có những biến chứng nặng nề cho các tạng và cấu trúc giải phẫu lân cận. Kết quả phẫu thuật tốt, không có tai biến, biến chứng nặng sau mồ. Kết quả lâu dài, nguyên nhân tử vong do ung thư tái phát, di căn.

Tư Khóa: Viêm loét trực tràng chảy máu, rò trực tràng âm đạo.

\section{SUMMARY}

\section{RESULTS OF TREATMENT COMPLICATIONS} RADIATION-INDUCED CERVICAL CANCER

Objective: Evaluation the results of treatment for complications caused by radiation therapy for cervical cancer. Methods: Retrospective study on 37 patients

\section{${ }^{1}$ Bệnh viện $K$ \\ ${ }^{2}$ Trung tâm hậu môn trực tràng Bệnh viện Việt Đức Chịu trách nhiệm chính: Nguyễn Đức Duy \\ Email: ducduy272@gmail.com \\ Ngày nhận bài: 23.6.2021}

Ngày phản biên khoa họ: 17.8.2021

Ngày duyệt bài: 25.8.2021

\section{Nguyễn Đức Duy ${ }^{1}$, Nguyễn Xuân Hùng ${ }^{2}$}

diagnosed with gastrointestinal, genitourinary complications caused by radiation therapy for cervical cancer who were operated at Viet Duc hospital from $2 / 2007$ to $12 / 2020$. Results: $100 \%$ of patients had bleeding rectal ulcer, of which 18 patients (48.6\%) had complications of stenosis and genitourinary organs fistula. Some other genitourinary complications: cystitis 8 patients $(21.6 \%)$, ureteral stenosis 8 patients $(21.6 \%)$, vaginal stenosis (no fistula into the rectum) 26 patients $(70.3 \%)$. Indication for surgery mainly due to bleeding rectal ulcers $19 / 37$ patients $(51.4 \%)$. Surgical removal of the lesion (Mille and Hartmann procedures) is the mainly for 27 patients, accounting for $73 \%$. Proctectomy, hysterectomy, cystectomy, coloanal anastomosis and colostomy for $6 / 37$ patients $(16,2 \%)$. There was no complications, severe complications postoperative, and there was no deaths. Long-term results, 7 patients died from local recurrence, or metastasis, accounting for $19 \%$. The postoperative patients are healthy, participate in community activities relatively normally, no longer have gastrointestinal bleeding. Conclusion: Radiation therapy for cervical cancer still has severe complications for adjacent organs and anatomical structures. Surgery brought good results, there was no complications and serious complications after surgery. Long-term results, the cause of death is cancer recurrence and metastasis. fistula.

Keywords; rectal ulcer bleeding, rectovaginal

\section{I. ĐĂT VẤN ĐỀ}

Ung thư ổ tử cung là môt trong những ung thư hay gặp ở nữ giới. Điều trị ung thư cổ tử cung dựa vào giai đoạn của bệnh. Ớ Việt Nam, điều trị ung thư cổ tử cung chủ yếu là xạ trị kết hợp với phẫu thuật, do bệnh thường phát hiện giai đoạn muộn. Tia xạ có khả năng tiêu diệt tế bao ung thư, nhưng tia xạ cũng gây ra những tổn thương các tổ chức, tạng lân cận. Các biến chứng thường gặp như: viêm loét trực tràng chảy máu, rò trực tràng âm đạo, hẹp hậu môn, viêm rò bàng quang...

Điều trị các biến chứng do xạ trị ung thư cổ 